\title{
POTENSI PEMBUATAN GULA NON-DIGESTIBLE DARI SELULOSA DAN HEMISELULOSA MENGGUNAKAN HIDROLISIS ENZIMATIS
}

\author{
(The Potential for Non-Digestible Sugar Production from Cellulose and Hemicellulose \\ using Enzymatic Hydrolysis)
}

\author{
Sunrixon Carmando Yuansah
}

Sekolah Menengah Atas Negeri 1 Sungailiat. Kep. Bangka Belitung, Indonesia

Email Penulis Korespondensi: sunrixoncy@gmail.com

\begin{abstract}
ABSTRAK
Selulosa dan hemiselulosa merupakan komponen biomassa lignoselulosa yang sangat melimpah di alam dan memiliki potensi dikembangkan sebagai salah satu bahan pangan yaitu gula yang tidak dapat tercerna (non-digestible sugar). Tujuan dari penulisan artikel ini adalah untuk menggali potensi pemanfaatan substrat selulosa dan hemiselulosa sebagai bahan alternatif pembuatan gula non-digestible. Pemanfaatan selulosa dan hemiselulosa dalam pembuatan non-digestibe sugar dapat dilakukan dengan biodegradasi menggunakan hidrolisis ezimatik. Hidrolisis enzimatis dipilih karena umumnya lebih ramah lingkungan daripada hidrolisis secara kimiawi menggunakan asam atau basa maupun hidrolisis fisik yang membutuhkan energi tinggi. Enzim-enzim yang digunakan merupakan enzim selulolitik dan hemiselulolitik dimana produk yang dihasilkan berupa disakarida seperti selobiosa dan oligosakarida seperti xilooligosakarida (XOS), manooligosakarida (MOS) dan selodekstin serta jenis gula lainnya yang merupakan turunan selulosa dan hemiselulosa.
\end{abstract}

Kata Kunci : gula non-digestible, hemiselulosa, selulosa.

\section{ABSTRACT}

Cellulose and hemicellulose are components of lignocellulose biomass that are very abundant in nature and have the potential to be developed as one of the food ingredients, such as non-digestible sugar. The purpose of writing this article is to explore the potential use of cellulose and hemicellulose substrates as an alternative ingredient in the production of non-digestible sugars. The utilization of cellulose and hemicellulose in the production of nondigestible sugar can be done by biodegradation using ezymatic hydrolysis. Enzymatic hydrolysis is chosen because it is generally more environmentally friendly than chemical hydrolysis using acids or bases or physical hydrolysis which requires high energy. The enzymes used are cellulolytic and hemicellulolytic enzymes where the products produced are disaccharides such as cellobiose and oligosaccharides such as xylooligosaccharides (XOS), manooligosaccharides (MOS) and cellodextrins and other types of sugars which are cellulose and hemicellulose derivatives.

Keywords : cellulose, hemicellulose, non-digestible sugar

\section{PENDAHULUAN}

Selulosa dan hemiselulosa merupakan komponen penyusun utama limbah lignoselulosa yang pemanfaatannya masih sangat terbatas dibidang pangan. Selulosa dan hemiselulosa banyak ditemukan terutama pada dinding sel tumbuhan yang dimana kedua komponen ini diselubungi oleh lignin. Struktur selulosa, hemiselulosa dan lignin ini merupakan penyusun biomassa bahan lignoselulosa seperti 
limbah pertanian (jerami gandum, bagasse tebu dan tongkol jagung), hasil hutan (kayu keras dan kayu lunak) dan tanaman khusus (rumput gajah dan gandarusa) (Kumar et al, 2009). Ketersediaan bahan-bahan ini sangat melimpah akan tetapi cenderung menjadi limbah akibat pemanfaatannya yang masih belum dikembangkan optimal.

Komposisi polimer selulosa dan hemiselulosa pada limbah lignoselulosa merupakan potensi yang sangat baik untuk dikembangkan. Selulosa yang merupakan homopolisakarida yang tersusun dari glukosa dan diikat oleh ikatan $\beta-(1,4)$ yang tidak dapat dicerna oleh sistem pencernaan manusia. Begitupun hemiselulosa yang merupakan heteropolisakarida yang tersusun dari monomer gula seperti mannan, xilan, glukan dan galaktan. Glukosa merupakan gula yang tidak dapat dicerna tetapi kedua polisakarida ini dapat menjadi prebiotik yang dapat memberi nutrisi bagi mikrobiota usus.

Pemanfaatan polimer selulosa dan hemiselulosa umumnya terbatas pada penggunaan industri non-pangan seperti pembuatan bioethanol, pupuk, pakan dan sebagainya. Walaupun, sudah ada produk selulosa yang dikembangkan untuk bahan pangan seperti nata, akan tetapi, masih banyak produk pangan yang dapat dikembangkan dari turunan produk ini, sama halnya dengan hemiselulosa (Yuansah, Darmawan, Nurdian, \& Laga, 2019). Selulosa dan hemiselulosa dapat dimanfaatkan sebagai alternatif sumber gula yang tidak dapat dicerna (nondigestible sugar) melalui proses degradasi secara emzimatis menjadi gula disakarida atau oligosakarida . Tujuan dari penulisan artikel ini adalah untuk menggali potensi pemanfaatan substrat selulosa dan hemiselulosa sebagai bahan alternatif pembuatan gula non-digestible. Degradasi substrat selulosa dan hemiselulosa dapat dilakukan dengan hidrolisis menggunakan enzim (Laga, Dirpan, \& Anshari, 2019; Sukendar, Laga, Try, \& Siade, 2018)

\section{PEMBAHASAN}

\subsection{Potensi Sumberdaya Selulosa dan Hemiselulosa dari Sumber Lignoselulosa}

Lignoselulosa merupakan salah satu komponen biomassa yang sangat berlimpah di alam. Lignoselulosa dipertimbangkan sebagai salah satu komponen kimia organik paling melimpah di dunia dan telah menarik perhatian, baik sebagai sumber energi langsung dan produksi bahan bakar, pakan ternak, produksi bahan kimia ataupun bahan pangan (Betts et al, 1991). Komponen utama lignoselulosa adalah selulosa, hemiselulosa dan lignin yang terikat erat satu sama lain membentuk kompleks seluler dari biomassa tumbuhan seperti pada dinding sel tumbuhan. Selulosa membentuk struktur rangka yang diselubungi oleh hemiselulosa dan lignin (Gambar 1)

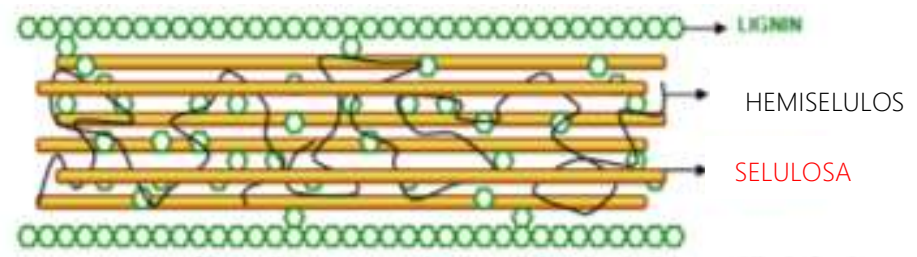

Gambar 1. Representasi Struktur Lignoselulosa yang Menunjukkan Fraksi Selulosa, Hemiselulosa dan Lignin.

Tabel 1. Komposisi Kimia dari Biomassa Lignoselulosa

\begin{tabular}{lcccc}
\hline $\begin{array}{l}\text { Biomassa } \\
\text { Ligno- } \\
\text { selulosa }\end{array}$ & $\begin{array}{c}\text { Selulosa / Hemiselulosa / Lignin } \\
\text { Hexosan } \\
(\mathbf{H})\end{array}$ & Pentosan (P) & & \\
\hline $\begin{array}{l}\text { Bagase Tebu } \\
\text { Jerami }\end{array}$ & $33(\mathrm{H})$ & $30(\mathrm{P})$ & 29 & $\begin{array}{l}\text { Kuhad dan } \\
\text { Singh, 1993 }\end{array}$ \\
$\begin{array}{l}\text { Gandum } \\
\text { Jerami }\end{array}$ & $33(\mathrm{H})$ & $24(\mathrm{P})$ & 18 & \\
$\begin{array}{l}\text { Sorgum } \\
\text { Jerami Padi }\end{array}$ & $32(\mathrm{H})$ & $24(\mathrm{P})$ & 13 & \\
$\begin{array}{l}\text { Jerami Oat } \\
\text { Bonggol }\end{array}$ & $41(\mathrm{H})$ & $16(\mathrm{P})$ & 11 & \\
$\begin{array}{l}\text { Jagung } \\
\text { Batang }\end{array}$ & $35(\mathrm{H})$ & $39(\mathrm{P})$ & 14 & \\
Jagung & $15(\mathrm{P})$ & 19 & \\
Sekam Padi & $36(\mathrm{H})$ & $15(\mathrm{P})$ & 19 & \\
$\begin{array}{l}\text { Serbuk } \\
\text { Gergaji }\end{array}$ & 55 & 14 & 21 & Olsson dan \\
Kertas Koran & 61 & 16 & 21 & Hagerdal, \\
\hline
\end{tabular}

Sumber : Chandel et al., (2007) 
Selulosa merupakan salah satu bagian dari karbohidrat yang merupakan polimer (homopolisakarida) dari monomer glukosa dengan dihubungkan ikatan glikosidik $\beta$ $(1,4)$. Selulosa memiliki berat molekul tinggi dan memiliki struktur kimia yang linear dimana unit dari selobiosa berulang membentuk polimer (Klemm et al, 1998). Polimer selulosa rantai panjang diikat oleh ikatan hidrogen dan ikatan van der Walls, yang menyebabkan selulosa membentuk mikrofibril. Kemampuan selulosa untuk membentuk mikrofibril akan membuat struktur daerah kristalin semakin besar dan menurunnya daerah struktur amorph yang berdampak pada kelarutan yang rendah dan lebih sulit didegradasi (Zhang \& Lynd, 2004). Produk hidrolisis enzim dari selulosa dapat berupa selooligosakarida, selobiosa maupun glukosa. Sedangkan, hemiselulosa adalah heteropolisakarida bercabang yang tersusun dari lima jenis gula berbeda (Larabinosa, D-galaktosa, D-glukosa, Dmannosa, and D-xilosa) dan beberapa komponen lainnya seperti asetat, glukoronat dan asam ferulik. Berdasarkan residu gulanya, hemiselulosa digolongkan menjadi xilan, mannan, glukan, glukuronoxilan, arabinoxilan, glukomannan, galaktomannan, galaktoglukomannan, xiloglukan dan $\beta$ glukan (Fengel \& Wegener, 1984). Hemiselulosa lebih mudah dihidrolisis daripada selulosa karena strukturnya yang bercabang sehingga daerah amorph yang terbentuk lebih besar. Produk hirolisat dari hemiselulosa dapat berupa xilobiosa, arabinoxilan dan xilooligosakaarida (Brasseur et al., 2014).

Lignin merupakan bagian terluar dari struktur biomassa lignoselulosa. Lignin berperan dalam struktur tanaman sebagai penguat, penahan serangan mikroba dan tekanan oksidasi. Lignin memiliki struktur heteropolimer amorph dimana tersusun dari tiga unti fenilpropan seperti p-coumaryl, coniferil dan sinapyl alkohol yang terikat dengan beragam ikatan (Anindyawati, 2010; Hendriks \& Zeeman, 2009). Struktur lignin yang kompleks membuatnya sulit didegradasi (Anindyawati, 2010), oleh

karena itu, lignin biasanya dipisahkan dengan selulosa dan hemiselulosa untuk mendapatkan hasil terbaik. Umumnya, pemanfaatan lignin hanya pada industri non pangan saja. Beberapa temuan terbaru mengembangkan lignin sebagai bahan baku pembuatan vanillin.

\subsection{Pretreatment Biomassa \\ Lignoselulosa dan Pemisahan Selulosa dan Hemiselulosa}

Pretreatment merupakan salah satu tahapan yang dilakukan untuk mengoptimasi produksi dalam pemanfaatan selulosa dan hemiselulosa pada biomassa lignoselulosa. Pretreatment dilakukan sebagai salah satu cara mempercepat proses hidrolisis dengan enzim dan meningkatkan rendemen hasil yang didapatkan. Pretreatment dapat dilakukan secara fisik, fisiko-kimia, kimia dan biologi. Beberapa pretreatment yang dapat dilakukan yaitu secara mekanik (dipotong, digerus, digiling), secara fisik (iradiasi dengan microwave, pirolisis, iradiasi gama), secara fisiko-kimia (steam explosion, ammonia fiber explotion (AFEX), cairan air panas), secara kimia (agen oksidasi (Ozonolisis $\mathrm{O}_{3}$ dan $\left.\mathrm{H}_{2} \mathrm{O}_{2}\right)$, alkali $\left(\mathrm{NaOH}, \mathrm{Ca}(\mathrm{OH})_{2}\right)$, penambahan asam $\left(\mathrm{HCl}, \mathrm{H}_{2} \mathrm{SO}_{4}, \mathrm{H}_{3} \mathrm{NO}_{3}\right)$, asam organik (asam malat, asam glutarat, dan sebagainya) serta proses organosolv (Anindyawati, 2010; Isikgora \& Becer, 2015). Menurut Saha (2003), metode pretreatment dapat dibedakan menjadi metode mekanik, perlakuan asam, perlakuan alkali dan perlakuan dengan menggunakan larutan organik (Tabel 2).

Tabel 2. Metode Pretreatment Biomassa Lignoselulosa

\begin{tabular}{ll}
\hline Metode & Contoh \\
\hline Mekanik & $\begin{array}{l}\text { Digerus, digiling, } \\
\text { digunting, extruder }\end{array}$ \\
Autohidrolisis & $\begin{array}{l}\text { Supercritical } \mathrm{CO}_{2} \\
\mathrm{H}_{2} \mathrm{SO}_{4} \text { dan } \mathrm{HCl} \\
\text { Perlakuan Asam }\end{array}$ \\
& $\begin{array}{l}\mathrm{encer}, \mathrm{H}_{2} \mathrm{SO}_{4} \text { dan } \\
\mathrm{HCl} \text { pekat }\end{array}$ \\
Perlakuan Basa & $\mathrm{NaOH}$, amonia, $\mathrm{H}_{2} \mathrm{O}_{2}$ \\
Perlakuan Larutan & $\begin{array}{l}\text { metanol, etanol, } \\
\text { butanol, fenol }\end{array}$ \\
Organik & Sumber : Saha, (2003)
\end{tabular}


Pretreatment umumnya didahului dengan proses pengecilan ukuran bahan baku yang melalui perlakuan mekanik seperti pencacahan, penggilingan, pemotongan, pengerusan dan sebagainya hingga diperoleh ukuran yang sama. Tujuan dari perlakukan awal ini adalah untuk memudahkan dalam tahapan pretreatment selanjutnya. Pengecilan ukuran bahan juga dilakukan dengan tujuan memudahkan kerja enzim dalam menghidrolisis substrat sehingga mengefisienkan waktu dalam proses sakarifikasi.

Pretreatment menggunakan metode steam explosion, autohidrolisis dan perkolasi dengan ammonia telah dilaporkan dapat menghilangkan komponen lignin untuk mendapatkan hemiselulosa (Anindyawati, 2010; Shimizu et al., 1998; Yoon, 1998). Penggunaan metode lain seperti supercritical $\mathrm{CO}_{2}$ dan ammonia fiber expansion (AFEX) juga dilaporkan dapat meningkatkan efektifitas dari hasil yang didapat. Kim \& Hong (2001) melaporkan bahwa penggunaan metode supercritical $\mathrm{CO}_{2}$ meningkatkan gula pereduksi dari 14,5 menjadi $84,7 \%$ terhadap kayu keras dan 12,8 menjadi 27,3\% terhadap kayu lunak sedangkan Balan et al. (2009) melaporkan bahwa AFEX dapat menghasilkan hasil efektif kurang lebih 98\% glukosa.

\subsection{Hidrolisis Selulosa dan Hemiselulosa Secara Enzimatis untuk Produksi Gula Non-Digestable}

Tahap hidrolisis dengan enzim merupakan tahap utama dalam proses sakarifikasi atau produksi gula nondigestible. Tahap hidrolisis dilakukan dengan enzim selulolitik dan hemiselulolitik untuk memecah komponen selulosa dan hemiselulosa yang sudah didapatkan dari tahap pretreatment lignoselulosa. Hidrolisis menggunakan enzim dipilih karena kerjanya yang spesifik, tidak seperti cara kimia dan mikrobiologi yang menghasilkan produk yang acak dan kurang dapat terkontrol. Selain itu, hidrolisis enzim memiliki nilai ramah lingkungan daripada menggunakan hidrolisis asam dan basa serta tidak membutuhkan energi yang besar.

Hidrolisis enzimatis merupakan alternatif yang dikembangkan dari hidrolisis asam dimana memiliki kerja yang sangat spesifik dan dapat dilakukan dalam kondisi reaksi mild (Umumnya $\mathrm{pH}$ diantara 5 dan suhu kurang dari $50^{\circ} \mathrm{C}$ ). Selain itu, hidrolisis enzim tidak mengakibatkan masalah korosi sehingga menghasilkan hasil murni gula dengan produk samping rendah (Liao et al., 2005; Martín et al., 2007). Dalam tahap enzimatis, gula disakarida dan oligosakarida dari hidrolisis selulosa dan hemiselulosa dipertahankan untuk mendapatkan gula non-digestible. Oleh karena itu, digunakan enzim $\beta-1,4-$ endoglukanase (EC 3.2.1.4) dan $\beta-1,4-$ eksoglukanase atau selobiohidrolase (EC 3.2.1.91) untuk menghasilkan selobiosa dan selooligosakarida dari hidrolisis selulosa. Sedangkan, hemiselulosa dihidrolisis dengan enzim xilanase dan mannase, dimana produk yang dihasilkan dapat berupa xilooligosakarida dan manooligosakarida yang berpotensi sebagai prebiotik bagi mikrobiota usus seperti Lactobacillus sp. dan Bifidobacterium sp. (Pangerang \& Rusyant, 2018; Sigres \& Sutrisno, 2015).

Produk lain dari hidrolisis enzim ini juga dapat berupa monosakarida seperti xilan, manan, glukan, galaktan, dan glukosa tetapi dalam konsentrasi yang kecil. Proses hidrolisis dari variasi jenis enzim ini stabil bekerja pada kondisi pH 5,5-7 dengan suhu optimal $60-80^{\circ} \mathrm{C}$. Untuk menjaga stabilitas kerja enzim dalam menghidrolisis substrat bahan baku selulosa dan hemiselulosa digunakan $\mathrm{CaCl}_{2}$ sebagai kofaktor enzim. Produksi gula Non-digestable yang dihasilkan dari hasil hidrolisis enzim ini dilakukan proses sakarifikasi selama 72 jam untuk memperoleh gula terbaik. 


\section{KESIMPULAN}

Selulosa dan hemiselulosa merupakan komponen yang masih memiliki nilai tambah ekonomis dalam biomassa lignoselulosa seperti limbah hutan dan agro-industri. Pembuangan limbah lignoselulosa langsung ke alam dapat berakibat pada masalah lingkungan disamping itu juga, membuang dengan percuma substansi yang masih dapat dimanfaatkan. Umumnya, pemanfaatan limbah lignoselulosa berfokus pada industri non-pangan walaupun beberapa sudah dimanfaatkan dalam industri pangan tetapi belum banyak yang dapat dimanfaatkan dengan optimal. Pemanfaatan selulosa dan hemiselulosa dari limbah lignoselulosa menjadi produk gula non-digestible melalui hidrolisis enzimatis berpotensi sebagai salah satu bahan pangan alternatif dan sebagai salah satu penanganan limbah lignoselulosa.

\section{DAFTAR PUSTAKA}

Anindyawati, T. (2010). Potensi Selulase Dalam Mendegradasi Lignoselulosa Limbah Pertanian Untuk Pupuk Organik. Berita Selulosa, 45(2), 70-77. Balan, V., Bals, B., P.S., S., Chundawat, Marshall, D., \& Dale, B. E. (2009). Lignocellulosic Biomass Pretreatment Using AFEX. In Methods in Molecular Biology (pp. 875-908). https://doi.org/10.1016/B978-0-12809597-3.00125-5

Betts, B., Dart, R. K., Ball, A. S., \& Pedlar, S. L. (1991). Biosythesis and Structure of Lignocelullose. In W. . Betts (Ed.), Biodegradation. https://doi.org/10.1007/978-1-44713470-1

Brasseur, C., Bauwens, J., Tarayre, C., Mattéotti, C., Thonart, P., Destain, J., De Pauw, E. (2014). MALDI-TOF MS Analysis of Cellodextrins and Xylooligosaccharides Produced by Hindgut Homogenates of Reticulitermes santonensis. Molecules, 19(4), 4578-
4594.

https://doi.org/10.3390/molecules1904 457

Chandel, A. K., Chan, E., Rudravaram, R., Narasu, M. L., Rao, L. V., \& Ravindra, P. (2007). Economics and environmental impact of bioethanol production technologies: an appraisal. Biotechnology and Molecular Biology Review, 2(1), 14-32.

Fengel, D., \& Wegener, G. (1984). Wood: chemistry, ultrastructure, reactions. Journal of Polymer Science Part C: Polymer Letters, 22(11).

Harmsen, P., Huijgen, W., Bermudez, L., \& Bakker, R. (2010). Literature review of physical and chemical pretreatment processes for lignocellulosic biomass. Food \& Biobased Research, (54), 154.

Hendriks, A. T. W. M., \& Zeeman, G. (2009). Pretreatments to enhance the digestibility of lignocellulosic biomass. Bioresource Technology. https://doi.org/10.1016/j.biortech.2008 .05 .027

Isikgora, F. H., \& Becer, C. R. (2015). Lignocellulosic biomass: a sustainable platform for the production of biobased chemicals and polymers. Polymer Chemistry, 6, 4497-4559. https://doi.org/10.1039/c5py00263j

Kim, K. H., \& Hong, J. (2001).

Supercritical CO2 pretreatment of lignocellulose enhances enzymatic cellulose hydrolysis. Bioresource Technology. https://doi.org/10.1016/S09608524(00)00147-4

Klemm, D., Philipp, B., Heinze, T., Heinze, U., \& Wagenknecht, W. (1998). Comprehensive Cellulose Chemistry Chichester: Wiley VCH

Kumar, P., Barrett, D. M., Delwiche, M. J., \& Stroeve, P. (2009). Methods for pretreatment of lignocellulosic biomass for efficient hydrolysis and biofuel production. Industrial and Engineering Chemistry Research, 48(8), 3713-3729. 
https://doi.org/10.1021/ie801542g

Laga, A., Dirpan, A., \& Anshari, A. A.

(2019). Pengaruh Konsentrasi Substrat pada Pembuatan Maltodekstrin Dari

Substrat Pati Sagu (Effect Of Substrate

Concentration Variation In

Maltodextrin Production From Sago

Starch). Canrea Journal: Food

Techology, Nutritons, and Culinary

Journal, 1(1), 23-30.

https://doi.org/10.20956/canrea.v1i1.1

9

Liao, W., Wen, Z., Hurley, S., Liu, Y., Liu, C., \& Chen, S. (2005). Effects of hemicellulose and lignin on enzymatic hydrolysis of cellulose from dairy manure. Applied Biochemistry and Biotechnology - Part A Enzyme Engineering and Biotechnology. https://doi.org/10.1385/ABAB:124:13:1017

Martín, C., De Moraes Rocha, G. J., Pérez, M., López, Y., Hernández, E., \& Plasencia, Y. (2007). Acid prehydrolysis, alkaline delignification and enzymatic hydrolysis of rice hulls. Cellulose Chemistry and Technology, 41(2-3).

Mussatto, S. I., \& Teixeira, J. A. (2010). Lignocellulose as raw material in fermentation processes. 897-907.

Pangerang, F., \& Rusyant, N. (2018). Karakteristik dan Mutu Beras Lokal Kabupaten Bulungan Kalimantan Utara. Canrea Journal: Food Techology, Nutritons, and Culinary Journal, 1(2), 107-117. https://doi.org/10.20956/canrea.v1i2.9 6

Saha, B. C. (2003). Hemicellulose bioconversion. Journal of Industrial Microbiology and Biotechnology. https://doi.org/10.1007/s10295-0030049-x

Shimizu, K., Sudo, K., Ono, H., Ishihara, M., Fujii, T., \& Hishiyama, S. (1998). Integrated process for total utilization of wood components by steamexplosion pretreatment. Biomass and Bioenergy.
https://doi.org/10.1016/S0961 9534(97)10044-7

Sigres, D. P., \& Sutrisno, A. (2015). Enzim Mannase dan Aplikasi di Bidang Industri : Review. Enzim Mananase Dan Aplikasi Di Bidang Industri, 3(3), 899-908.

Sukendar, N. K., Laga, A., Try, D., \& Siade, P. (2018). Studi Pengawetan Larutan Enzim Bromelin Kasar Secara Filtrasi dan Penambahan Natrium Benzoat (Study Of Preservation Crude Bromelain Enzyme By Filtration And Addition Of Sodium Benzoate). Canrea Journal: Food Techology, Nutritons, and Culinary Journal, 1(1), 63-68.

https://doi.org/10.20956/canrea.v1i1.2 3

Yoon, H. H. (1998). Pretreatment of lignocellulosic biomass by autohydrolysis and aqueous ammonia percolation. Korean Journal of Chemical Engineering. https://doi.org/10.1007/BF02698990

Yuansah, S. C., Darmawan, Nurdian, F., \& Laga, A. (2019). Pengaruh Pretreatment Jerami Padi pada Produksi Enzim Termostabil Menggunakan Isolat Bkteri Termofilik. Canrea Journal: Food Techology, Nutritons, and Culinary Journal, 2(1), 13-18. https://doi.org/10.20956/canrea.v2i1.1 75

Zhang, Y. P., \& Lynd, L. R. (2004). Toward an Aggregated Understanding of Enzymatic Hydrolysis of Cellulose : Noncomplexed Cellulase Systems. Biotechnology and Bioengineering Journal, 88(7). https://doi.org/10.1002/bit.20282 